\title{
The Rise of Private Military and Security Companies in European Union Migration Policies: Implications under the UNGPS
}

\author{
Daria DAVITTI*1
}

\begin{abstract}
This article examines the involvement of Private Military and Security Companies (PMSCs) in both shaping and implementing the European Agenda on Migration (European Agenda), launched by the European Union in May 2015. The migration policies which have since been adopted have increasingly enabled the outsourcing to private security contractors of various border control operations, including those related to forced returns, administrative detention and security services for the Italian and Greek 'hotspots'. The article argues that PMSCs frame, shape and entrench militarized responses in the European Agenda. It also contends that the current context of the European refugee 'crisis' meets the conditions of a high-risk context, as understood within the United Nations Guiding Principles on Business and Human Rights (UNGPS). This re-definition of the refugee 'crisis' as a high-risk context, in turn, enables the identification of heightened human rights obligations of home states and responsibilities of companies when implementing the UNGPs.
\end{abstract}

Keywords: EU migration policies, high-risk areas, Private Military and Security Companies, UNGPs

\section{INTRODUCTION}

Over the last year, discussions by business and human rights scholars and practitioners in relation to refugee protection have mainly focused on the exploitation of refugees in company operations and global supply chains. ${ }^{2}$ In this article, I do not intend to suggest that this focus is inappropriate, as the exploitation of refugees - children and adults alike

* Postdoctoral Researcher, Lund University, Faculty of Law and Assistant Professor, University of Nottingham, School of Law; email: daria.davitti@jur.lu.se and daria.davitti@nottingham.ac.uk

1 This article was presented at the Third Business and Human Rights Scholars Conference at Santa Clara University in September 2017. I am grateful to the organisers and participants for their feedback, to the anonymous reviewer, the editors and Michelle Staggs Kelsall for their comments, and to Marlene Fries for her excellent research assistance and support during her internship at the Forced Migration Unit, Human Rights Law Centre, University of Nottingham in the summer/autumn of 2017. All websites were last accessed 9 September 2018, unless otherwise stated.

2 See, e.g., Samentha Goethals et al, 'Business and Human Rights Responsibility for Refugees and Migrant Workers: Turning Policies into Practice in the Middle East' (2017) 2 Business and Human Rights Journal 335. See also Emre Eren Kormaz, 'How Do Syrian Refugee Workers Challenge Supply Chain Management in the Turkish Garment Industry' International Migration Institute Working Paper No. 133 (March 2017), https://www.imi.ox.ac.uk/files/news/ wp133-how-do-syrian-refugee-workers-challenge-supply-chain-management-in-the-turkish-garment-industry.pdf 
- along the supply chains of various industries is unfortunately a significant issue that needs to be further examined and better addressed. Instead, I wish to take the discussion to a different locale, which I argue presents equally crucial challenges in terms of addressing the implications of abuses perpetrated against people on the move.

I focus specifically on the involvement of Private Military and Security Companies $(\mathrm{PMSCs})^{3}$ in both shaping and implementing the European Agenda on Migration (European Agenda), launched by the European Union (EU) in May 2015 in response to a sharp rise in the number of deaths at sea while attempting to reach EU shores. ${ }^{4}$ The policies which have since been adopted by the EU and its Member States to respond to the refugee "crisis' ${ }^{5}$ have increasingly enabled the outsourcing to PMSCs of various migration control operations, including inter alia those related to deportations and removal, housing, transport, the detention of refugees and the security of reception and/or processing centres, such as the 'hotspots' in Italy and Greece. ${ }^{6}$

\footnotetext{
3 Although the security industry and most states prefer the term Private Security Contractors (or PSC), in this paper I adopt the term PMSC to reflect the fact that armed contractors can use force in self-defence, which in turn entrenches the trend towards the militarization of EU migration policies. This terminology also enables a focus on the multiple activities and on the various types of private security actors involved in migration control. For further details on terminology, see Nigel White, 'Regulation of the Private Military and Security Sector: Is the UK Fulfilling its Human Rights Duties?' (2016) 16 Human Rights Law Review 585. For a definition of PMSC, see ICRC and Swiss Federal Government, 'Montreux Document: On Pertinent International Legal Obligations and Good Practices for States Related to Operations of Private Military and Security Companies' (17 September 2008), Preface, para 9: 'PMSCs are private business entities that provide military and/or security services, irrespective of how they describe themselves. Military and security services include, in particular, armed guarding and protection of persons and objects, such as convoys, buildings and other places; maintenance and operation of weapons systems; prisoner detention; and advice to or training of local forces and security personnel'. See also International Code of Conduct Association, 'International Code of Conduct for Private Security Service Providers' (ICoC), finalized in November 2010, which provides the following definition: 'Private Security Companies and Private Security Service Providers (collectively "PSCs") - any Company (as defined in this Code) whose business activities include the provision of Security Services either on its own behalf or on behalf of another, irrespective of how such Company describes itself' (emphasis added); see: https://www.icoca.ch/ en/the_icoc\#b-definitions. For the purpose of my analysis, the security services provided by PMSCs also include, e.g., the provision, operation and/or maintenance of border technologies and surveillance equipment such as drones, maritime/air and other vehicles, as well as the provision of on-the-ground personnel, providing armed guarding and protection, as well as the daily administration of immigration detention.

4 Approximately 1,850 people died across the Mediterranean during the first five months of 2015, against an estimated 3,139 people dying or missing throughout the whole of 2017. For comparison, the estimated figure up to and including 23 April 2018 is of 522 people dying or missing across the Mediterranean. See: https://data2.unhcr.org/en/ situations/mediterranean

5 I hold the view that the current situation in Europe does not amount to a refugee crisis, as it is mainly self-induced, and the direct result of the policies of externalization and securitization adopted by the EU and its member states, as partly described in this paper. It does, however, reflect a political willingness to justify brutal measures to stop refugee arrivals by depicting the situation as a humanitarian emergency. For a similar view, see Ruben Andersson, 'The European Union's migrant "emergency" is entirely of its own making', The Guardian (23 August 2015), http://www. theguardian.com/commentisfree/2015/aug/23/politics-migrants-europe-asylum. For the argument on humanitarian posturing, see Daria Davitti, 'Biopolitical Borders and the State of Exception in the European Migration Crisis' (2018) 29:4 European Journal of International Law (forthcoming).

6 For a list of contracts signed between the European Asylum Support Office (EASO) and various PMSCs in 2017, covering a wide-range of asylum services, see, e.g., EASO, 'List of Contracts Awarded by the European Asylum Support Office in 2017 in Accordance with Article 124 of the Commission Delegated Regulation (EU) No 2462/2015 of 30 October 2015 on the Rules of Application of Regulation (EU, Euratom) No 1929/2015 of the Financial Regulation Applicable to the General Budget of the Union', https://www.easo.europa.eu/sites/default/files/EASO-contractsawarded-2017.pdf. This list includes, for instance, a controversial contract with G4S Secure Solutions S.A. to provide security for the 'hotspots' in the Aegean islands in Greece, following riots in 2016. See also 'Silver Linings: Migration, Terrorism and Austerity Help Contractors to Prosper', The Economist (25 June 2016), https://www.economist.com/ business/2016/06/25/silver-linings. See further Jane Lethbridge, 'Privatisation of Migration and Refugee Services and Other Forms of State Disengagement', Public Services International Research Unit (2017), http://www.world-psi.org/ en/privatisation-migration-refugee-services-other-forms-state-disengagement.
} 
The scope and nature of the human rights abuses occurring at the hands of PMSCs implementing EU migration-control policies is well known and has been accurately documented. $^{7}$ Yet, achieving remedy for victims of business-related human rights abuses taking place in migration settings remains an intractable challenge, not least for the jurisdictional hurdles faced by the victims and for the non-state-actor status of PMSCs, who are traditionally not directly bound by international law. ${ }^{8}$ The nature of the abuses and the difficulties encountered in ensuring effective remedies in the context of business' involvement in migration control were emblematically evidenced in the recent Kamasaee $v$ Commonwealth case, a class action suit against the Commonwealth of Australia and two corporate contractors in charge of operating the immigration detention centre on Manus Islands in the Independent State of Papua New Guinea (one of which, notoriously, was G4S) - a case that was eventually settled without admission of liability for AUD\$70 million plus costs. ${ }^{9}$

The main objective of this article is not to articulate in detail the obligations of the home states and the responsibilities of relevant PMSCs in contexts of migration control, but rather to put forward three key arguments which will hopefully engender a debate within the Business and Human Rights community of scholars and practitioners, in relation to the possible responses to the abuses taking place during the implementation of the policies of cooperative deterrence ${ }^{10}$ which characterize the EU response to the ongoing migration 'crisis'. My aim is to detail and justify the conceptual and practical applicability of relevant UNGP standards to the context of migration control. Legal scholars may argue that a focus on the UNGPs, as taken throughout this article, should be further supplemented by, e.g., a discussion of EU member states' responsibility under

\footnotetext{
7 See, e.g., Martin Lemberg Pedersen, 'Private Security Companies and the EU Borders' in Thomas GammeltoftHansen and Ninna Nyberg Sørensen (eds), The Migration Industry and the Commercialization of International Migration (Abington: Routledge, 2013) 152-172; Michael Flynn, 'From Bare Life to Bureaucratic Capitalism: Analyzing the Growth of the Immigration Detention Industry as a Complex Organization' (2016) 8(1) Contemporary Readings in Law and Social Justice 70. See also Nathan Ward, 'Panorama's Exposé of Immigration Centre Abuse is No Surprise. I Saw it for Myself', The Guardian (7 September 2017), https://www.theguardian.com/commentisfree/2017/ sep/07/panorama-g4s-abuse-expose-immigration-centre-brook-house. See more generally the database published by the project The Migrant Files, detailing the contracts related to border security and deportation, as well as to software and hardware developed and provided for the implementation of EU migration policies up until June 2016, http://www. themigrantsfiles.com/.

8 A major difficulty is the reluctance of home states to regulate the overseas activities of companies registered or domiciled in their jurisdiction, which in turn contributes to what is known within the Business and Human Rights discourse as a 'governance gap' between the human rights standards of protection enshrined in relevant human rights instruments and reflected in the UNGPs, on the one hand, and the measures undertaken by states and companies, on the other. Much has been written on this governance gap and on how the issue of extraterritoriality and jurisdiction should (or should not) be addressed: see inter alia Olivier De Schutter, 'Towards a New Treaty on Business and Human Rights' (2016), 1 Business and Human Rights Journal 41; Robert McCorquodale and Penelope Simons, 'Responsibility Beyond Borders: State Responsibility for Extraterritorial Violations by Corporations of International Human Rights Law' (2007) 70:4 Modern Law Review 598; Philip Alston (ed) Non-State Actors and Human Rights (New York: Oxford University Press, 2005); Daria Davitti, 'Refining the Protect, Respect and Remedy Framework for Business and Human Rights and its Guiding Principles' (2016) 16 Human Rights Law Review 55; Sara L Seck, 'Home State Responsibility and Local Communities: The Case of Global Mining' 11:1 Yale Human Rights and Development Law Journal 178 (2008). For a contrasting view, see Claire Methven O'Brien, 'The Home State Duty to Regulate the Human Rights Impact of TNCs Abroad: A Rebuttal' (2018) 3 Business and Human Rights Journal 47.

9 For an excellent analysis of the case, see Gabrielle Holly, 'Transnational Tort and Access to Remedy under the UN Guiding Principles on Business and Human Rights: Kamasaee v Commonwealth' (2018) 19 Melbourne Journal of International Law 52.

10 For the term 'cooperative deterrence', see further Thomas Gammeltoft-Hansen and James C Hathaway, 'NonRefoulement in a World of Cooperative Deterrence' (2015) 53 Columbia Journal of Transnational Law 235.
} 
the Articles on State Responsibility for Internationally Wrongful Acts (ARSIWA) ${ }^{11}$ and PMSC responsibilities under the International Code of Conduct for Private Security Service Providers (ICoC), ${ }^{12}$ issued by the International Code of Conduct Association (ICoCA). Whilst I agree that a discussion of these instruments could further supplement the analysis undertaken in this article, I have chosen to focus on the applicability of the UNGPs to the migration context, and the obligations and responsibilities enshrined therein, as this is now considered the primary soft law instrument setting out what is to be expected of states and business to protect and respect human rights. As such the UNGPs are understood as reflecting standards already existing in international law. This is particularly pertinent, given that several EU member states, including Italy, ${ }^{13}$ have committed to implementing the UNGPs through national action plans (NAPs). Yet, these same states fail to consider the applicability of the UNGPs to obligations arising within the context of the European Agenda, with considerable implications for the conduct of PMSCs. It is outside the scope of the current investigation, therefore, to further consider obligations under other instruments (e.g. ARSIWA and ICoC). ${ }^{14}$

The three main arguments put forward in this article, therefore, are structured as follows. First, in section II, I argue that PMSCs' involvement in the framing, shaping and entrenchment of militarized responses by the EU through the European Agenda is pervasive. These private non-state actors, in fact, not only provide advanced border security and migration control services to member states and their partners (increasingly non-EU countries of transit and origin), but are also heavily involved in setting the priorities of the EU defence and security research agenda. Evidence indicates ${ }^{15}$ that in so doing, they contribute to the framing of irregular migration as a security threat which can only be addressed through emergency-driven military responses - and, conveniently, the same services provided by PMSCs. These private non-state actors, therefore, irreversibly shape European migration policies and the ever-increasing privatized securitization of

11 United Nations, International Law Commission (23 April to 1 June and 2 July to 10 August 2001) General Assembly Official Records, Fifty-fifth Session, Supplement No 10 (A/56/10), http://www.un.org/law/ilc/.

$12 \operatorname{ICoC}(2010)$ note 3.

13 See Italian Inter-Ministerial Committee for Human Rights (CIDU) 'Italian National Plan on Business and Human Rights, 2016-2021', http://www.cidu.esteri.it/resource/2016/12/49117_f_NAPBHRENGFINALEDEC152017.pdf. The Italian NAP, e.g., explicitly mentions both conflict and high-risk areas in relation to UNGP 7 and refers to the OECD due diligence guidance 'Risk Awareness Tool for Multinational Enterprises in Weak Governance Zones' and 'Due Diligence Guidance for Responsible Supply Chains of Minerals from Conflict-Affected and High-Risk Areas'.

14 For an evaluation of the soft law initiatives aimed at regulating PMSCs, see generally Sorcha MacLeod and Rebecca DeWinter-Schmitt, 'Auditing and Certification of Management Systems for Private Security Operations: An Effective Tool for Ensuring Private Security Companies Meet their Responsibility to Respect Human Rights?' (2018) in this special issue. The examination of state responsibility for the conduct of PMSCs under ARSIWA is certainly desirable and recommended for further research. It is also the aim of a broader research project in which I am currently involved, entitled Liquid Borders, which examines inter alia the potential joint responsibility and/or complicity of EU member states, cooperating third countries, of the EU itself (under ARIO) and of private non-state actors involved in the implementation of the European Agenda. For the first output of the project, setting out the theoretical underpinning of the analysis, see Davitti, (2018) note 5.

15 See Chris Jones, 'Market Forces: The Development of the EU Security-Industrial Complex', Transnational Institute (25 August 2017), https://www.tni.org/en/publication/market-forces-the-development-of-the-eu-securityindustrial-complex. See also Mark Akkerman, 'Border Wars, The Arms Dealers Profiting from Europe's Refugee Tragedy', Stop Wapenhandel and Transnational Institute (4 July 2016) and 'Border Wars II, An Update on the Arms Industry Profiting from Europe's Refugee Tragedy', Stop Wapenhandel and Transnational Institute (December 2016), https://www.tni.org/en/publication/border-wars. 
the EU borderscape, ${ }^{16}$ within a context of self-perpetuating convergence of interests between the EU and major security providers. ${ }^{17}$

In section III, after briefly describing the involvement of PMSCs in the context of EU migration control and the human rights risks that such involvement engenders, I then argue that the current context of the European refugee 'crisis' meets the conditions of a high-risk area for the purposes of the application of the UNGPs. ${ }^{18}$ As I evidence in this paper, this characterization is particularly appropriate to the privatization of the migration control services both within EU member states and at the increasingly externalized EU border (from the management of deportations and removals, to the running of immigration detention facilities, to the operationalization of housing and health care services, and the distribution of food vouchers, etc.). The definition of 'highrisk' is also apposite to describe EU-funded interception operations at sea, as well as the conditions in countries of transit and origin, not least in the Sahel and North Africa, to which EU member states are externalizing specific border control functions, and propose to also transfer asylum determination processing responsibilities. ${ }^{19}$ In section IV, I explain that this re-definition of the migration control measures enshrined in the European Agenda as high-risk operations for the purposes of business and human rights would enable scholars and practitioners to identify heightened human rights obligations of home states and increased due diligence responsibilities of PMSCs involved in implementing EU migration policies. Importantly, this re-definition as a high-risk area would also implicitly shift the emphasis away from the conceptualization of the current migration situation as a 'crisis', i.e. an emergency for the EU and its member states, by highlighting instead the high risk of occurrence of gross abuses in this context and the importance of focusing on safeguarding the rights of people on the move.

\section{A Perfect Business Model: How PMSCs Shape and Implement EU Policies on Migration}

The first argument presented in this article is that PMSCs are significantly influential in shaping EU migration policies in such a way that they become almost indispensable to the practical development and implementation of such policies. This involvement is

\footnotetext{
16 On the interdisciplinary use of the term 'borderscape', see, e.g., Chiara Brambilla, 'Exploring the Critical Potential of the Borderscapes Concepts' (2015) 20 Geopolitics 14.

17 According to Barbara Unmüßig, President of the Heinrich-Böll-Stiftung, and Ska Keller, Member of the European Parliament, '[w] hat we witness is a convergence of business interests and the aims of political hardliners who view migration as a threat to the EU's homeland security': Ben Hayes and Mathias Vermeulen, 'Borderline: The EU's Border Surveillance Initiatives' Heinrich-Böll-Stiftung (June 2012), https://www.tni.org/files/download/borderline.pdf.

18 Human Rights Council, 'Guiding Principles on Business and Human Rights: Implementing the United Nations' "Protect, Respect and Remedy” Framework', A/HRC/17/31 (21 March 2011).

19 See, e.g., 'European Council Conclusions 28 June 2018' at I.5, where the European Council called 'on the Council and the Commission to swiftly explore the concept of regional disembarkation platforms, in close cooperation with relevant third countries as well as UNHCR and IOM. Such platforms should operate distinguishing individual situations, in full respect of international law and without creating a pull factor' (emphasis added), http://www. consilium.europa.eu/en/press/press-releases/2018/06/29/20180628-euco-conclusions-final/. See also the contextual situation described in Daria Davitti and Marlene Fries, 'Offshore Processing and Complicity in Current EU Migration Policies, Part 1' EJILTalk! Blog (10 October 2017), https://www.ejiltalk.org/offshore-processing-and-complicity-incurrent-eu-migration-policies-part-1/.
} 
problematic not only in terms of the symbiotic relationship it engenders, but also because of the way it accelerates the drive towards militarized responses to migration. ${ }^{20}$

As evidenced later in this section through the example of Leonardo S.p.A., it is possible to identify at least three levels of PMSC involvement in the current European refugee 'crisis'. This three-layered involvement largely reflects the group structure of major actors in the industry, which diversify their services - usually through complex group structures and subsidiaries - to be able to respond to different on-the-ground needs. The main actors involved in this area, therefore, specialize in tailored security services (from border monitoring services to sophisticated floating maritime surveillance systems) $;^{21}$ arms trade and production; security and policy research. Their involvement in EU migration policies can thus be traced firstly at the research level, whereby they contribute to framing irregular migration as a 'security threat' that can only be addressed through security technologies and solutions. The second level of involvement relates to the way in which PMSCs market their product and services as dual-use technologies. As evidenced by Theodore Baird, ${ }^{22}$ due to defence budget constraints and cuts, since 2008 many PMSC (such as Leonardo/Selex, Thales, Airbus, Altos and Indra) ${ }^{23}$ have accelerated their specialization in dual-use technologies which can be easily adapted from combat situations to civilian environments, including border and migration control contexts. Their third level of involvement can be identified in their lobbying activities; with a turnover of $€ 97.3$ billion in $2014,{ }^{24}$ they represent a sector of major financial significance to the EU. The industry is actively represented by influential lobby groups, primarily the Aerospace and Defence Industries Association of Europe (ASD) ${ }^{25}$ and the European Organisation for Security (EOS) ${ }^{26}$ which seek to inform, and to the extent possible influence, EU policies, including in relation to migration control and border security.

As mentioned above, an emblematic example of this three-layered involvement in the European Agenda on Migration is that of the Italian company Leonardo S.p.A. (formerly

20 On the negative implications or current militarized responses to forced migration, see Sumbul Rizvi, 'The New Migration Landscape: The Implications of a Militarised Response to Smuggling', in Tuesday Reitano et al (eds), Militarised Responses to Transnational Organised Crime (Cham: Palgrave Macmillan, 2018) 187-202.

21 Daniel Real-Arce et al, 'A New Integrated Border Security Approach: The FP7 PERSEUS Project' (2016) 50 Marine Technology Society Journal 14.

22 Theodore Baird, 'Interest Groups and Strategic Constructivism: Business Actors and Border Security Policies in the European Union' (2018) 44 Journal of Ethnic and Migration Studies 118, 123.

23 Many of these private actors are simultaneously arms producers and security service providers, and their involvement in migration control reflects the multifaceted nature of their corporate groups. Airbus, for instance, provides 'integrated security solutions' which include research and provision of technologies and services in the (civilian) context of border security, as well as integrated weapons systems and technologies (in contexts of armed conflict); see: https://www.airbus.com/defence/security-solutions.html. See also Akkerman (2016) note 15, 'Border Wars', 31-33. Since 2016 Germany has been providing military and border security equipment to Tunisia, mainly produced by Airbus and Hensoldt (Airbus' former border security division). See, e.g., Inken Bartels, 'Fortress Europe in North Africa' Taz (12 December 2016), http://www.taz.de/!5417074/. See also Mark Akkerman, 'How the Security Industry Reaps the Rewards of EU Migration Control' (4 June 2018), https://www.newsdeeply.com/refugees/ community/2018/06/04/how-the-security-industry-reaps-the-rewards-of-e-u-migration-control.

24 Fact Sheet of the European Union, 'Defence Industry', http://www.europarl.europa.eu/atyourservice/en/displayFtu. html?ftuId=FTU_2.4.4.html. The border security market alone was valued at more than $€ 16$ billion in 2017; see Akkerman (2018), ibid.

25 http://www.asd-europe.org/about-us/members

26 http://www.eos-eu.com/Middle.aspx?Page=members\&tID=175. According to Jones (2017), note 15, in 2015 ASD and EOS had an annual declared lobby budget that amounted to approximately $€ 600,000$. 
Leonardo-Finmeccanica and Finmeccanica). In terms of research, for instance, Leonardo S.p.A. is involved in the EU-funded research programme Horizon 2020. ${ }^{27}$ Moreover, Selex Sistemi Integrati S.p.A., a subsidiary of Leonardo S.p.A., also conducted EU-funded research under the precursor of Horizon 2020, the 7th Framework for Research, for instance on 'sea border surveillance' for a project called Seabilla. ${ }^{28}$ The declared aims of the Seabilla project were to 'reduce the number of illegal immigrants [sic] attempting to enter the EU undetected; increase internal security by contributing to the prevention of cross-border crime;' and 'enhance search and rescue capabilities, especially to save more lives of migrants who attempt risky ways to cross the border' ${ }^{29}$ Seabilla focused on 'three main European sea areas (Atlantic, English Channel, Med) ... to develop solution to counter specific threats' ${ }^{30}$ The available information on Seabilla lists seven scenarios that include 'illegal migration' in the Atlantic, the Mediterranean and the English Channel. ${ }^{31}$

This research clearly frames anybody attempting to reach EU shores as 'illegal migrants', and in turn 'illegal' (rather than irregular) ${ }^{32}$ migration as a cross-border crime and a security threat, thus opening up the possibility for Selex Sistemi Integrati S.p.A. to offer security solutions for the situation at hand. Regardless of the terminology deployed in these research and development projects, it is important to recall that under international law, as enshrined both in international and regional instruments, there are clear standards of protection against torture and non-refoulement, ${ }^{33}$ as well as standards which ensure, inter alia, non-penalization for migrants' irregular entry, ${ }^{34}$ the right to leave, ${ }^{35}$ and the right to seek and enjoy asylum. ${ }^{36}$

These international legal standards are reflected in the UNGPs, whose 'normative contribution lies not in the creation of new international law obligations but in elaborating the implications of existing standards and practices for States and businesses;

27 Akkerman (2016), note 15, 'Border Wars' 30.

28 European Commission, 'EU Research for a Secure Society' (April 2016), https://ec.europa.eu/home-affairs/sites/ homeaffairs/files/what-we-do/policies/industry-for-security/docs/security_research_fp7_catalogue_part1_en.pdf, 304-305.

29 Ibid, 304 (emphasis added). Note how the definition of border-crossing as a crime contravenes the obligation of non-penalization for irregular entry, enshrined in Article 31 of the Refugee Convention: see note 33.

30 Ibid, 305 (emphasis added).

31 Ibid.

32 Stylianos Kostas, 'Irregular vs Illegal Immigration: Setting the Definitions. An Overview of European Practice' (2017) 65 Slovak Ethnology 420, 424-25.

33 The prohibition against refoulement is enshrined in various instruments, e.g., Article 33 of the 1951 Convention Relating to the Status of Refugees (Refugee Convention); Article 3 of the 1984 Convention against Torture and Other Cruel, Inhuman or Degrading Treatment or Punishment (CAT); and at the European regional level (particularly relevant for our argument) in Article 3 of the 1953 European Convention on Human Rights (ECHR). Non-refoulement is also recognized as a principle of customary international law: see Sir Elihu Lauterpacht and Daniel Bethlehem, 'The Scope and Content of the Principle of Non-Refoulement: Opinion' in Erika Feller et al (ed), Refugee Protection in International Law: UNHCR's Global Consultations on International Protection (2003) 87-177.

34 See, e.g., Article 31 of the Refugee Convention.

35 See, e.g., Article 13(2) of the Universal Declaration of Human Rights (UDHR); Article 12(2) of the International Covenant on Civil and Political Rights; Article 5 of the Convention on the Elimination of All Forms of Racial Discrimination 1966; Article 10(2) of the Convention on the Rights of the Child 1990; Article 8(1) of the International Convention on the Protection of the Rights of All Migrant Workers and Members of their Families; and at regional level Article 2 of Protocol No. 4 of the ECHR.

36 See Article 14(1) UDHR. 
integrating them within a single, logically coherent and comprehensive template; and identifying where the current regime falls short and how it should be improved'. ${ }^{37}$ Current migration control policies, however, at EU level and elsewhere, are mainly aimed at circumventing these obligations and at outsourcing migration control through cooperation based non-entrée policies, ${ }^{38}$ many of which see the direct or indirect involvement of PMSCs. ${ }^{39}$

Returning to the example of Leonardo S.p.A. selected for this article, its capacity to influence policy-making is apparent in the fact that, as of 2015, Leonardo-Finmeccanica (later renamed Leonardo S.p.A. in January 2017) was the ninth largest arms company/ defence contractor in the world. ${ }^{40}$ It is partially owned by the Italian Ministry of Economy and Finance (which is its largest shareholder) ${ }^{41}$ and a member of at least two well-known lobby organizations that represent the interests of security and arm companies, namely ASD and EOS. Both ASD and EOS have significant influence in shaping EU security policies. ${ }^{42}$ For instance, many members of the Protection and Security Advisory Group (PASAG), whose main task is to advise the European Commission on the Implementation of Horizon $2020,{ }^{43}$ were recently found to be connected to EOS members. ${ }^{44}$ Reportedly, 'many security advisory group members are closely linked to companies and institutions that win EU-funded security projects' ${ }^{45}$

Unsurprisingly, given the close and complex economic links between Italy and Libya, which are strictly connected to Italy's colonial history, ${ }^{46}$ in 2014 Selex Sistemi Integrati S.p.A. was involved in a border security deal with Libya funded by the EU and Italy, which included the supply of an advanced border control system. ${ }^{47}$ This contract is a clear example of the involvement of large defence contractors in third countries' border securitization, at a time in which the EU and its member states were already criticized for

37 United Nations Human Rights Council, Report of the Special Representative of the Secretary-General on the issue of human rights and transnational corporations and other business enterprises, Guiding Principles on Business and Human Rights: Implementing the United Nations 'Protect, Respect and Remedy' Framework (2011) UN Doc A/HRC/ 17/31, Annex; http://www.ohchr.org/documents/issues/business/A.HRC.17.31.pdf.

38 Gammeltoft-Hansen and Hathaway (2015), note 10, especially section II.

39 This involvement is clearly explained in the context of Australian Pacific Solution in Holly (2018), note 9, and further exemplified throughout this article in relation to the European context.

40 Aude Fleurant et al, 'SIPRI Top 100 Arms-Producing and Military Services Companies, 2014', SIPRI Fact Sheet (2015), https://www.sipri.org/sites/default/files/files/FS/SIPRIFS1512.pdf.

41 The fact that Leonardo S.p.A. is partially owned by the Italian Ministry of Economy and Finance has obvious legal implications in terms of state's obligations, which distinguish this PMSC from those who are privately owned and to whom international law applies as to other non-state actors. The example of Leonardo S.p.A., however, is still appropriate and useful to exemplify the three-layered involvement of PMSCs which this section addresses.

42 Crina Boros, 'How the EU Cosied up to the Defence Lobby', Investigate Europe, 21 December 2016, http://www. investigate-europe.eu/en/how-the-eu-cosied-up-to-the-defence-lobby/.

43 European Commission, 'Horizon 2020 Protection and Security Advisory Group (E03010)' (Register of Commission Expert Groups, 21 June 2017), http://ec.europa.eu/transparency/regexpert/index.cfm?do=groupDetail. groupDetail\&groupID=3010

44 Boros (2016), note 42.

45 Crina Boros, 'Graphic: Consultants linked to EU Contractors', http://www.tagesspiegel.de/downloads/14965018/2/ eos-connections-with-ue.pdf

46 See, e.g., David Atkinson, 'The Politics of Geography and the Italian Occupation of Libya' (1996) 27 Libyan Studies 71.

47 Akkerman (2016), note 15, 'Border Wars' 28. See also 'Libya Buys Border Control System from SELEX' (Defence Industry Daily, 12 October 2009), http://www.defenseindustrydaily.com/Libya-Buys-Border-Control-System-fromSELEX-05846/ 
externalizing the EU borders and for outsourcing migration controls to North African countries, in an attempt to ultimately circumvent their own human rights obligations. ${ }^{48}$

Notably, at the time of the involvement of Selex Sistemi Integrati S.p.A. in Libya, the conditions in the Libyan detention centres were such as to amount to inhuman and degrading treatment, and return to Libya as non-refoulement. The latter prohibition was indeed breached by Italy's policies of interception and pushback to Libya, as part of the cooperation agreement with Libya (as discussed in relation to the Hirsi case in section III below). By providing the Libyan authorities with an advanced border control system, it is possible to argue that Selex Sistemi Integrati S.p.A. may have contributed to such violations, and/or enabled the implementation of the migration control policies which were found to be in contravention of Article 3 of the European Convention of Human Rights (ECHR). ${ }^{49}$

According to official discussions in the European Parliament, it is also apparent that more recently Leonardo S.p.A. attended meetings with the European Border and Coast Guard (EBCG, formerly Frontex) where it presented various products tailored to the activities of the agency. ${ }^{50}$ This is of notable significance given the broader mandate of the EBCG, which includes, inter alia, authorization to directly intervene when member states are not doing enough to stem migration flows; to help set up 'hotspots' for the processing of asylum seekers; to coordinate Joint Operations at sea; and to be involved in 'return' operations. ${ }^{51}$ This broader mandate is matched by an increase in the budget allocated to the agency, ${ }^{52}$ which in turn increases the business opportunities available for PMSCs like Leonardo S.p.A.

This analysis of the involvement of PMSCs and their influence in shaping border security and migration control policies is of significance in better identifying how their activities, especially in the context of migration, can be regulated through the UNGPs in an attempt to prevent human rights harm. ${ }^{53}$ It is to this end that the article now turns to argue that key contextual situations and operations related to the European migration

\footnotetext{
48 Daria Davitti and Annamaria La Chimia, 'A Lesser Evil? The European Agenda on Migration and the Use of Aid Funding for Migration Control' (2015) 10 Irish Yearbook of International Law 133. See also Francesca Mussi and Nick F Tan, 'Comparing Cooperation on Migration Control: Italy-Libya and Australia-Indonesia' (2015) 10 Irish Yearbook of International Law 87; see in particular section II.

49 Council of Europe, European Convention for the Protection of Human Rights and Fundamental Freedoms, as amended by Protocols Nos 11 and 14, 4 November 1950, ETS 5.

50 European Commission, 'Reply on question E-0344/2017' (20 July 2017), http://www.statewatch.org/news/2017/ jul/eu-com-frontex-border-surveillance-company-presentations-answer-7-17.pdf

51 Regulation (EU) 2016/1624 of the European Parliament and of the Council of 14 September 2016 on the European Border and Coast Guard and amending Regulation (EU) 2016/399 of the European Parliament and of the Council and repealing Regulation (EC) No 863/2007 of the European Parliament and of the Council, Council Regulation (EC) No 2007/2004 and Council Decision 2005/267/EC.

52 See the critique in Sergio Carrera and Leonhard Den Hertog, 'A European Border and Coast Guard: What's in a Name?', CEPS Paper in Liberty and Security in Europe no 88/2016 (2016), https://www.ceps.eu/system/files/LSE\% 20No\%2088\%20SC \%20and\%20LdH\% 20EBCG.pdf

53 As mentioned earlier, this article focuses on the UNGPs not because they represent a source of obligations and responsibilities, but because they are considered by many a tool to prevent human rights harm through policy coherence, including in high-risk contexts. For an assessment of the effectiveness of this potential tool, see Daria Davitti, 'Article 4 UDHR and The Prohibition against Slavery: A Critical Look at Contemporary Slavery in Company Operations and Supply Chains' in Humberto Cantú Rivera (ed), The Universal Declaration of Human Rights: A Commentary (Leiden: Brill/Nijhoff, forthcoming 2019). For an evaluation of other soft law mechanisms for PMSCs, see MacLeod and DeWinter-Schmitt (2018), note 14, p 10-12, 24.
} 
'crisis' can be appropriately defined as high risk, for the purposes of the application of the UNGPs.

\section{Re-Defining the Policies of the European Agenda As High-Risk}

\section{OPERATIONS}

The second argument that I would like to put forward in this article flows directly from the first one: I submit that there is sufficient evidence to suggest that it is appropriate to characterize the context of the European Agenda as 'high risk' and that this re-definition, in turn, will enable a clearer and more targeted application of the standards enshrined in the UNGPs. As further discussed in section IV, this is particularly important to establish heightened obligations for the home states of the PMSCs involved, as well as specific responsibilities of the PMSCs themselves.

Although there is no agreed-upon definition of 'conflict-affected and high-risk areas, ${ }^{4}$ and principles 7 and 23(c) of the UNGPs refer to conflict-affected areas and to gross human rights abuses (see also section IV below), it is possible to resort to other relevant definitions of these terms, so as to evince their definitional content. The Organization for Economic Co-operation and Development (OECD), for instance, defines 'conflict-affected and high-risk areas' as follows:

[c]onflict-affected and high-risk areas are identified by the presence of armed conflict, widespread violence or other risks of harm to people. Armed conflict may take a variety of forms, such as a conflict of international or non-international character, which may involve two or more states, or may consist of wars of liberation, or insurgencies, civil wars, etc. High-risk areas may include areas of political instability or repression, institutional weakness, insecurity, collapse of civil infrastructure and widespread violence. Such areas are often characterised by widespread human rights abuses and violations of national or international law. ${ }^{55}$

Similarly, the EU definition of 'conflict-affected and high-risk areas' characterizes them as:

[a]reas in a state of armed conflict, fragile post-conflict areas, as well as areas witnessing weak or non-existing governance and security, such as failed states, and widespread and systematic violations of international law, including human rights abuses. ${ }^{56}$

If we apply the above conceptualizations to the European refugee 'crisis', various contextual elements suggest that current EU policies are implemented in high-risk areas and/or contexts that increasingly entail high-risk operations. In the remainder of this section I explain how this claim can be substantiated.

Primarily, since the launch of the European Agenda in 2015, a crucial theatre of the current refugee 'crisis' is Libya's territory, both on land and at sea. For the purposes of the application of the UNGPs, Libya also qualifies as a conflict-affected country (as per

\footnotetext{
54 United Nations Office of the High Commissioner for Human Rights (OHCHR), 'Due Diligence: Defining "Conflict-Affected" and "High-Risk Areas"' (Concept Note for a Side Event at the Business and Human Rights Forum 2013), http://www.ohchr.org/Documents/Issues/Business/ForumSession2/Events/3Dec.1.SideEventProposal_ GenevaAcademy.pdf

55 'Conflict-Affected and High-Risk Areas (CAHRAs)' (Conflict-Free sourcing initiative), http://www. conflictfreesourcing.org/training-and-resources/conflict-affected-and-high-risk-areas/

56 Ibid.
} 
UNGP 7), irrespective of whether we consider the country as still in a situation of armed conflict or in a post-conflict situation. ${ }^{57}$ Libya also meets the criteria applicable to a high-risk area, given the well-documented ${ }^{58}$ widespread violations of international law, including human rights abuses against migrants, occurring both in Libyan territorial waters and in official and unofficial detention centres scattered around the country. As mentioned in the previous section, Leonardo S.p.A. supplied border control systems to Libya at a time when these violations were already taking place, ${ }^{59}$ as confirmed by the decision by the European Court of Human Rights (ECtHR) in Hirsi Jaama and Others $v$ Italy, ${ }^{60}$ where the Court found that the Italian interceptions in the high sea and related pushback operations to return people to Libya were in breach of the prohibition against non-refoulement. More specifically, the Court held that the Italian authorities knew or should have known that the people returned to Libya "would be exposed in Libya to treatment in breach of the [Convention] and they would not be given any kind of protection in that country', ${ }^{61}$ in breach of Article 3 ECHR.

As already mentioned in section II, PMSCs involved in migration control activities at the time of the Italy-Libya cooperation agreement considered in Hirsi (such as Selex Sistemi Integrati S.p.A.), were at risk 'of causing or contributing to gross human rights abuses'. As such, they should have treated this risk as a legal compliance issue, as envisaged in UNGP 23(c). As clarified in the commentary to the latter principle, complex operating environments (such as the one characterizing the cooperation on migration between Italy and Libya) may increase the risk of being complicit in gross human rights abuses by other actors, therefore 'business enterprises should ensure that they do not exacerbate the situation. In assessing how best to respond, they will often be well advised to draw on not only expertise and cross-functional consultation within the enterprise, but also to consult externally with credible, independent experts, including from Governments, civil society, national human rights institutions and relevant multistakeholder initiatives'.

Within the context of Leonardo S.p.A.'s involvement in migration control measures through its subsidiary, it is likely that Italy, as the home state and major shareholder of Leonardo S.p.A., may have been involved in supporting some of the negotiations leading

\footnotetext{
57 However, reports of a further escalation of the conflict in Qasar Bengashir, only $30 \mathrm{~km}$ from Tripoli, were issued on 25 and 27 August 2018, confirming several clashes between brigades under the control of the Presidential Council's government Interior Ministry, and the forces securing Qasar Bengashir, including the Seventh Brigade of Defense Ministry based in Tarhouna. See Abdullah Benibrahim, 'Heavy Fighting Rocks Libyan Capital's Southern Districts', https://www.libyaobserver.ly/news/heavy-fighting-rocks-libyan-capital's-southern-districts

58 See OHCHR, 'Abuse Behind Bars: Arbitrary and Unlawful Detention in Libya' (10 April 2018), http://www.ohchr. org/Documents/Countries/LY/AbuseBehindBarsArbitraryUnlawful_EN.pdf. See also UNHCR's latest non-return advisory: UN High Commissioner for Refugees (UNHCR), UNHCR Position on Returns to Libya - Update II (September 2018), http://www.refworld.org/docid/5b8d02314.html; and see UNHCR, 'UNHCR Flash Update Libya (17-24 August 2018)', https://reliefweb.int/report/libya/unhcr-flash-update-libya-17-24-august-2018-enar, according to which 'UNHCR is gravely concerned about the worsening conditions for refugees and asylum-seekers detained in Libya. The situation is being compounded further by the limited prospects for solutions to their situation'; and see further UNGA, 'Unlawful Death of Refugees and Migrants: Report of the Special Rapporteur of the Human Rights Council on Extrajudicial, Summary or Arbitrary Executions, Agnes Callamard' (15 August 2017), UN Doc A/72/335. 59 OHCHR (2018), ibid, especially discussion in section II.

60 Hirsi Jamaa and Others $v$ Italy, ECtHR Grand Chamber, judgement of 23 February 2012, Application No 27765/09.

61 Ibid, para 131.
} 
to the conclusion of this deal. There is no evidence, however, that it provided advice and/ or support to Leonardo S.p.A. as envisaged in UNGP 7, i.e. to 'help them identify, prevent and mitigate the human rights-related risks of their activities and business relationships' (as per subsection (a) of the principle); and 'to assess and address heightened risks of abuses, paying special attention to both gender-based and sexual violence' (as per subsection (b)). ${ }^{62}$ As the Italian Ministry of Economy and Finance is the largest shareholder of this PMSC, Italy should have taken 'additional' steps to protect against human rights abuses by its own state-owned enterprise, as envisaged in principle 4 of the UNGPs. These 'additional' steps are complementary to the international obligations reflected in principles $1-3$ of the UNGPs, and in line with the need to achieve policy coherence (principle 8 of the UNGPs).

Crucially, the Council of Europe Committee of Ministers has also acknowledged the need for additional measures to be taken by states that own or control business enterprises. In its recommendations, the Committee specified that 'Member States should apply additional measures to require business enterprises to respect human rights, including, where appropriate, by carrying out human rights due diligence, that may be integrated into existing due diligence procedures, when member States ... own or control business enterprises'. ${ }^{63}$ Whilst there is no evidence that such 'additional' steps were undertaken by Italy, there is also no evidence that Leonardo S.p.A. engaged in activities aimed at assessing, mitigating and/or preventing human rights harm, as envisaged under pillar two of the UNGPs (business responsibility to respect).

As recent United Nations (UN) reports on Libya revealed, the human rights of people attempting to cross the Mediterranean to reach the EU continue to be severely violated. ${ }^{64}$ The Libyan Coast Guard ${ }^{65}$ is actively involved in 'pull back' operations, ${ }^{66}$ aimed at intercepting people attempting to leave Libya by sea and returning them to Libyan detention centres, where they are subject to torture and inhuman and degrading treatment. ${ }^{67}$ Recent evidence has emerged that Italy and the EU are involved in

\footnotetext{
62 UNGPs, note 18, Principle 7 and related commentary. UNGP 7 refers specifically to situations in which business may become involved in conflict-affected areas, and it has two other subsections, which I discuss further in section IV. For the purposes of completeness, however, these two subsections refer to 'denying access to public support and services for a business enterprise that is involved with gross human rights abuses and refuses to cooperate in addressing the situation' and 'ensuring that their current policies, legislation, regulations and enforcement measures are effective in addressing the risk of business involvement in gross human rights abuses'.

63 See recommendation $\mathrm{CM} / \operatorname{Rec}(2016) 3$ on human rights and business, para 22, as quoted in UN Doc A/HRC/32/45 (4 May 2016), note 98. See also Directive 2014/24, of the European Parliament and of the Council of 26 February 2014 on public procurement and repealing Directive 2004/18, 2014 O.J. (L 94) 65; Directive 2014/25 of the European Parliament and of the Council of 26 February 2014 on procurement by entities operating in the water, energy, transport and postal services sector and repealing Directive 2004/17/EC, 2014 O.J. (L 94) 243.

64 See various UN reports, note 58.

65 As there is no stable government in Libya, it has been argued that UN-backed government in Tripoli has no full control over the activities of the Libyan Coast Guard, and the UN High Commissioner for Human Rights, Zeid Ra' ad Al Hussein, strongly criticized the continued financial, technical and operational support that the EU and especially Italy continue to provide to it, despite the documented abuses perpetrated by its offices. See, e.g., OHCHR press release, 'UN Human Rights Chief: Suffering of Migrants in Libya Outrage to Conscience of Humanity', 14 November 2017, http:// www.ohchr.org/EN/NewsEvents/Pages/DisplayNews.aspx?NewsID=22393\&LangID=E

66 For the use of the term 'pull back' in relation to migration operations or policies, see Nora Markard, 'The Right to Leave by Sea: Legal Limits on EU Migration Control by Third Countries' (2016) 27 European Journal of International Law 591, 593-94.

67 See various UN reports, note 58.
} 
equipping and funding the Libyan Coast Guards with migration control systems, training and equipment, ${ }^{68}$ which are therefore used in operations that breach the prohibition against torture and against refoulement. Furthermore, it is important to note that such migration control measures are underpinned by the findings of research projects carried out by PMSCs and connected with the theme of 'illegal' migration in the Mediterranean Sea. Such projects are, for instance, the abovementioned Seabilla project ${ }^{69}$ and project 'Perseus' by Indra Sistemas S.A. ${ }^{70}$ There is little doubt that the conditions in Libya, both on land and at sea, meet the definitional criteria for conflict-affected and high-risk areas set out in the OECD and EU definitions, that is (at a minimum) a situation of 'political instability', 'collapse of civil infrastructure', 'widespread human rights abuses', 'violations of national or international law' and 'weak or non-existing governance and security'. 71

A closer analysis of the broader operational context of the European Agenda on Migration reveals the active engagement of PMSCs at different levels of policy implementation. According to Mark Akkerman, for instance, military drones were tested by the European Border and Coast Guard in the course of 2018 for maritime border surveillance in the Mediterranean Sea. ${ }^{72}$ More generally, the 2004-2020 budgets of the External Borders Fund, of the Internal Security Fund and of the Borders and Schengen Facility (amounting to approximately $€ 4.5$ billion) were used by EU member states to purchase border patrol vehicles and vessels, airplanes, surveillance systems, cameras, thermal vision equipment, and biometric and IT systems, many of which were supplied by EU-based PMSCs. ${ }^{73}$

As widely documented, the militarization and securitization of the EU borders has resulted in higher death tolls, as people are increasingly pushed towards more dangerous routes. ${ }^{74}$ In turn, a marked increase in human rights abuses has been recorded at various stages of the migration journey (examples range from deprivation of liberty and lack of

68 Mark Akkerman, 'Border Wars' (2016), note 15.

69 EU Research for a Secure Society (2016), note 28, 304.

70 Ibid, 302.

71 CAHRA definitions, note 55. For more information on the conditions of refugees in Libya and interception at sea, see Daniel Ghezelbash et al, 'Securitization of Search and Rescue at Sea: The Response to Boat Migration in the Mediterranean and Offshore Australia' (2018) 67 International and Comparative Law Quarterly 315. See also Oxfam, 'You Aren't Human Any More: Migrants Expose the Harrowing Situation in Libya and the Impact of European Policies' (Oxfam, MEDU and Borderline Sicilia, 9 August 2017), https://reliefweb.int/report/libya/you-arent-humanany-more-migrants-expose-harrowing-situation-libya-and-impact-european

72 The military drones tested in this context were the Heron from Israeli Aerospace Industries Ltd, and the Falco from Leonardo S.p.A. These PMSCs secured, respectively, €4.75 million for 600 hours of trial flights, and $€ 1.7$ million for 300 hours of trial flights. See Akkerman (2016), note 15.

73 Reportedly, Airbus SE provided helicopters to Finland and Romania and Leonardo S.p.A. to Bulgaria, Croatia, Cyprus, Estonia, Italy, Latvia and Malta: see ibid. See also a further report by Akkerman (released after submission of this article): Mark Akkerman, 'Expanding the Fortress: The Policies, the Profiteers and the People shaped by EU's Border Externalisation Programme' (Stop Wapenhandeln/TNI, 2018) at https://www.tni.org/en/publication/expandingthe-fortress

74 Ibid, Akkerman, 2018. See also Ruben Andersson, 'Rescued and Caught: The Humanitarian-Security Nexus at Europe's Frontiers' in Nicholas De Genova (ed), The Borders of 'Europe': Autonomy of Migration, Tactics of Bordering (Durham: Duke University Press, 2017). See also Thomas Spijkerboer, 'High Risk, High Return: How Europe's Policies Play into the Hands of People-Smugglers', The Guardian, 20 June 2018 at https://www.theguardian. com/world/commentisfree/2018/jun/20/how-europe-policies-accelerate-people-smuggling; and Thomas Spijkerboer, 'Bifurcation of People, Bifurcation of Law: Externalization of Migration Policy before the EU Court of Justice' (2018) 31:2 Journal of Refugee Studies 216. 
due process; inhuman and degrading treatment and conditions in detention centres; lack of access to appropriate medical care, food and water; and sexual and other violence). ${ }^{75}$

In order to provide a more detailed contextualization of the policies of cooperative deterrence that characterize current EU migration control, it is important to note that some of the other EU partners identified as 'priority third countries' under the Partnership Framework, ${ }^{76}$ for instance Mali and Niger, are also likely to meet the OECD and EU definitions, given their complex political and socio-economic situations. Some of these countries are in fact listed as medium- or high-risk countries on various risk maps often used by states for official risk assessments. ${ }^{77}$ The EU has also started discussing country packages for further cooperation on migration with 16 priority partners, including countries such as Afghanistan in which armed conflict is still ongoing. 78

The implications of such a decision by the EU and its member states to increase their cooperation on migration with conflict-affected and high-risk countries are multifaceted. Undoubtedly these interventions risk exacerbating already fragile and precarious situations, thus potentially leading to an escalation of the armed conflicts existing in these areas. ${ }^{79}$ The EU is also prioritizing the aims of its own external action agenda (e.g. reducing the numbers of people reaching EU shores and therefore able to claim asylum in EU member states) at the expense of safeguarding an already compromised regional and international balance in its partner countries, including in the fragile Sahel region. Both Italy and France, for instance, have increased their military presence in the region over the past few years, ${ }^{80}$ and other EU member states were considering similar steps during the spring of $2018 .^{81}$

75 See, e.g., Lethbridge (2017), note 6. See also Akkerman, ibid.

76 European Commission, 'A European Agenda on Migration' (13 May 2015) COM(2015) 240 final, https://ec. europa.eu/anti-trafficking/sites/antitrafficking/files/communication_on_the_european_agenda_on_migration_en.pdf; see also European Commission, 'Communication on Establishing a New Partnership Framework with Third Countries under the European Agenda on Migration' (7 June 2016) COM(2016) 385 final, https://ec.europa.eu/home-affairs/sites/ homeaffairs/files/what-we-do/policies/european-agenda-migration/proposal-implementation-package/docs/20160607/ communication_external_aspects_eam_towards_new_migration_ompact_en.pdf

77 Control Risks, 'Risk Map' (Control Risks, 2016), http://riskmap.controlrisks.com/wp-content/uploads/2016/12/ RiskMap-2017.pdf; Heidelberg Institute for International Conflict Research, 'Conflict Barometer 2016' (HIIK, 2017), https://www.hiik.de/en/konfliktbarometer/pdf/ConflictBarometer_2016.pdf; Index for Risk Management, 'Country Profile' (INFORM), http://www.inform-index.org/Countries/Country-Profile-Map

78 Partnership Framework (2016), note 76. The EU has already entered into an agreement with Afghanistan, the 'Joint Way Forward', which foresees the prioritization of cooperation on migration and the willingness on the part of the Afghan government to swiftly accept back Afghan citizens returned from EU member states. Controversially, the negotiations related to this agreement made EU development aid for the reconstruction and stabilisation of Afghanistan conditional to agreeing to 'cooperate' on migration. See 'Joint Way Forward' agreement with Afghanistan signed in October 2016, EU Doc 12191/16 of 22 September 2016.

79 For an analysis of the risks in Niger, see further Fransje Molenaar et al, 'A Line in the Sand: Roadmap for Sustainable Migration Management in Agadez' (Clingendael, 2017).

80 Daria Davitti and Anca-Elena Ursu, 'Why Securitising the Sahel Will Not Stop Migration', University of Nottingham Human Rights Law Centre FMU Policy Brief No 02/2018 (10 January 2018), https://www.nottingham.ac. uk/hrlc/documents/fmu-policy-brief/pb-2-why-securitising-the-sahel-won't-stop-migration.pdf

81 On the German military contribution to Mali, see Ben Knight, 'Germany to Expand Global Military Missions' Deutsche Welle, 7 March 2018, http://www.dw.com/en/germany-to-expand-global-military-missions/a-42858081. On the impact of EU migration policies in Niger, see further Joe Penney, 'Europe Benefits by Bankrolling an Anti-Migrant Effort. Niger Pays a Price', The New York Times, 25 August 2018, https://www.nytimes.com/2018/08/25/world/africa/ niger-migration-crisis.html 
As skilfully documented by the field work of the Clingendael Netherlands Institute of International Relations, the escalating securitisation of North Africa and the Sahel by the EU and its member states, however, including for the purposes of migration control, is not a new phenomenon. ${ }^{82}$ Extractive and other geopolitical interests in these regions have ensured that the EU always kept close links with key countries and a military presence in the area.

The European Agenda on Migration, crucially, explicitly links migration control to the security aims of EU member states, by ensuring that 'migration will become a specific component of ongoing Common Security and Defence Policy (CSDP) missions already deployed in countries like Niger and Mali, which will be strengthened on border management'. ${ }^{83}$ The Valletta Summit Action Plan of 2015 also identified as one of its objectives the 'prevention of and fight against irregular migration, migrant smuggling and trafficking in human beings' hereby explicitly connecting the prevention of irregular migration from African countries with the fighting of transnational crimes such as migrant smuggling and human trafficking. ${ }^{84}$

In the European Commission's Joint Declaration on the EU legislative priorities for $2017^{85}$ migration and security were further interconnected with each other, as 'better protection of [EU] external borders' was prioritized under the heading of 'better protecting the security of our citizens, ${ }^{86}$ In a Joint Communication of the Commission and High Representative of January $2017,{ }^{87}$ migration and security were also linked by a reference to the 'fight' against smugglers and traffickers through the European Maritime Security Strategy Action Plan and a stronger CSDP engagement with the G5 Sahel Force, the joint military and security force of Niger, Burkina Faso, Chad, Mali and Mauritania. ${ }^{88}$

For the specific purposes of this article, it is important to note that, by crystallizing the security dimension of EU migration policies, the interventions outlined so far exponentially increase the business opportunities for PMSCs, who already have longstanding expertise in these high-risk areas. Increased securitization of migration control in fragile and unstable contexts, however, also intensifies the risk of PMSCs' involvement in violations of international law perpetrated by states within the context of ongoing migration policies under the European Agenda on Migration.

Crucially, and as discussed in section II, this establishment of a link between migration and security was already identified as in need of prioritization in the research outputs of EU-funded research projects (for instance within the remit of EU Research for a Secure

\footnotetext{
82 See, e.g., Fransje Molenaar and Floor El Kamouni-Janssen, 'Turning the Tide: The Politics of Irregular Migration in the Sahel and Libya' (Clingendael, 2017), https://www.clingendael.org/publication/turning-tide

83 Partnership Framework (2016), note 76, 5.

84 Participants of the Valletta Summit on Migration, 'Valletta Summit Action Plan' (11-12 November 2015), file:/// C:/Users/llxmf11/Downloads/POLITICAL_DECL_EN\%20(1).pdf

85 European Commission, 'Joint Declaration on the EU's legislative priorities for 2017' (13 December 2016), https:// ec.europa.eu/commission/sites/beta-political/files/joint-declaration-legislative-priorities-2017-jan2017_en.pdf

86 Ibid, 12.

87 European Commission, 'Migration on the Central Mediterranean Route - Managing Flows, Saving Lives' (25 January 2017) JOIN(2017) 4 final, https://ec.europa.eu/home-affairs/sites/homeaffairs/files/what-we-do/policies/ european-agenda-migration/proposal-implementation-package/docs/20170125_migration_on_the_central_mediterranean_ route_-_managing_flows_saving_lives_en.pdf

88 Ibid, 12
} 
Society) carried out by PMSCs themselves. ${ }^{89}$ By explicitly connecting migration control to the European Maritime Security Strategy Action Plan, to EUCAP ${ }^{90}$ and CSDP missions, and to policies to fight transnational crimes and increase the security of European citizens, migration is irrevocably identified and addressed as a 'security threat'. This discourse, in turn, also ensures access to EU security funds for the purposes of migration control, enables the lowering of restrictions on data sharing on refugees and asylum seekers, and more generally justifies the implementation of draconian measures to tackle irregular migration. ${ }^{91}$

The security dimension in which EU migration policies are enveloped makes PMSCs ideally placed to offer their security services and expertise, ${ }^{92}$ not only in countries in which an armed conflict is ongoing (such as Libya and Afghanistan) or which are in a post-conflict situation, but more broadly in any migration control setting, in the EU and elsewhere. The general security approach to the European refugee 'crisis' is such that everyday services for refugees and asylum seekers are also increasingly contracted out to PMSCs: from immigration detention facilities to deportation and removal services, ${ }^{93}$ from housing, to access to health care services and distribution of food vouchers, ${ }^{94}$ all these 'services' are managed by (largely the same) PMSCs. ${ }^{95}$

In light of what has been examined so far, it is possible to argue that the securitized context in which EU migration policies are implemented means that the security services flowing from these policies and the PMSCs contracted to provide them should be subjected to a higher level of scrutiny, not least through the direct application of the UNGPs. Principles 7 and 23(c) expressly refer to conflict-affected areas and gross abuses. It is argued, however, that these principles also hold relevance in high-risk areas where there is a risk of gross human rights abuses taking place, including within the context of migration control.

\footnotetext{
89 'EU Research for a Secure Society' (2016), note 28, 305.

90 See, e.g., the EUCAP Sahel Niger and EUCAP Sahel Mali capacity building missions to enhance processes of regional security cooperation, run by the EU External Action Service, and identified by the Joint Communication of January 2017 as key to 'managing migrant flows through the southern border', note 87, 12-16.

91 Davitti (2018), note 5. For more details on how EU policies of externalization are affecting key African states, see Anne Koch et al, 'Diversity of Cooperation Contexts as a Challenge to the EU' in Anne Koch et al (eds), Profiteers of Migration? Authoritarian States in Africa and European Migration Management (Stiftung Wissenschaft und Politik/ German Institute for International and Security Affairs, 2018) SWP Research Paper 4, 66, https://www.swp-berlin.org/ en/publication/profiteers-of-migration/

92 The Economist, 'Silver Lining: Security Businesses in Europe Set to Profit from Migration Crisis', https://www. economist.com/news/business-and-finance/21700844-migration-terrorism-and-austerity-help-contractors-prosperprivate-security-firms-are

93 Lydie Arbogast, 'Migrant Detention in the European Union: A Thriving Business' (Migreurop and RosaLuxemburg-Stiftung, 2016), https://www.rosalux.eu/leadmin/user_upload/Publications/MIGRANT-DETENTIONEU-EN.pdf

94 Lethbridge (2017), note 6.

95 Ibid, 20-27. On the conflicts of interest between the EU and the security industry, see p 25-26, where it is explained that the EU 7th Framework Research Programme (FP7) 'provided funding for several security research projects which are given to research institutes which work in partnership with private companies which produce security systems, for example, Thales, BAE, IAI or EADS'.
} 


\section{The European Refugee ‘Crisis’: Heightened Home States’ Obligations AND PMSCs’ RESPONSIBILITIES}

\section{A. Gross Abuses and Heightened Home States' Obligations}

As evidenced so far in this article, it is appropriate to conceptualize the EU policies on migration control and securitization, aimed at tackling the European refugee 'crisis', as pertaining to high-risk operations for the purpose of implementing the UNGPs. The EU itself appears to have no concern in framing such policies as part of security operations to combat human trafficking, smuggling and terrorism, and more broadly as enhanced measures for the security and protection of EU citizens. PMSCs themselves are involved in research projects that frame current migration flows as a security threat to the EU which requires increased security measures. It is only reasonable, therefore, to ensure that the outsourced services flowing from these security policies are subject to higher scrutiny, as it is pertinent for security policies and services deployed in high-risk or conflict contexts.

The third argument that I put forward in this article, is that for the purposes of a business and human rights analysis, the direct consequence of such a reconceptualization of the policies developed within the European Agenda on Migration is that the home states of PMSCs operating in these highly securitized contexts have heightened human rights obligations, whilst the PMSCs providing these services have increased responsibilities, as envisaged by the UNGPs. Although home states and PMSCs themselves might at first be reluctant to support this approach, I advance the argument that it would enable a clearer understanding of the obligations vested upon home states and, in turn, of the relevant human rights due diligence responsibilities ${ }^{96}$ expected of PMSCs operating in a high-risk migration context.

Despite the justifiable critique of the restrictive policies adopted to tackle the refugee "crisis', 97 there is no sign that the EU and its member states will abandon the European Agenda on Migration any time soon. Thus, whereas it would be preferable to see an overall rethink of the current EU approach to migration control, in the meantime it is important to argue that both home states and PMSCs are subject, respectively, to heightened human rights obligations and responsibilities.

As mentioned in section III, in cases such as Leonardo S.p.A., where the company is partly owned by the state, home states are also expected to take additional steps to protect against human rights abuses by state-owned companies, as envisaged by UNGP $4 .{ }^{98}$ These 'additional' steps are supplementary to the international obligations reflected in principles 1-3 and 7 of the UNGPs, further examined here. The majority of PMSCs involved in the European Agenda, however, are not state-owned enterprises, so my focus in this subsection is mainly on the enhanced obligations articulated in UNGP 7

\footnotetext{
96 See, e.g., R Davis, 'The UN Guiding Principles on Business and Human Rights and Conflict-Affected Areas: State Obligations and Business Responsibilities' (2012) 94 International Review of the Red Cross 961.

97 See, e.g., Marianna Kariakoulaki et al (eds), Critical Perspectives on Migration in the Twenty-First Century (E-International Relations Publishing, 2018), https://www.e-ir.info

98 In relation to these cases, see UN Human Rights Council, Report of the Working Group on the issue of human rights and transnational corporations and other business enterprises, 'Leading by Example: The State, State-Owned Enterprises, and Human Rights', UN Doc A/HRC/32/45 (4 May 2016). In this report, the Working Group considered the specific duty of states to protect against human rights abuses involving those business enterprises that they own or control (generally referred to as State-owned enterprises).
} 
and relevant to the home states of companies operating in conflict affected and high-risk contexts.

According to UNGP 7, home states of PMSCs involved in the implementation of the European Agenda on Migration are expected to 'help them identify, prevent and mitigate the human rights-related risks of their activities and business relationships' and 'to assess and address heightened risks of abuses'. ${ }^{99}$ As expanded in the commentary and in a report in an addendum to the UNGPs, ${ }^{100}$ home states' engagement is to be understood as in addition to the engagement of host states where the PMSC are deployed. Home states' engagement should be proactive and take place as early as possible:

because prevention is cheaper than reaction for both States and business enterprises. It is furthermore more likely that engagement can be effective in helping business enterprises to avoid involvement in human rights abuse if it takes place before violence becomes widespread. Nonetheless, prevention might not be enough, and States should remain engaged with the business enterprise through the conflict cycle. ${ }^{101}$

As convincingly argued by Radu Mares, a close analysis of UNGP 7 and of its commentary reveals that this principle is "conceptually dependent on "gross abuses" and not on the conflict context' ${ }^{102}$ Gross abuses are to be understood as more serious human rights abuses than 'severe impacts' or 'significant risks', referred to for instance in other principles. ${ }^{103}$ The first two provisions of the commentary to UNGP 7, Mares contends, 'couple the increased likelihood of occurrence (high-risk areas) with the grossness of the abuse' in order to ensure that home states are proactive and supportive of cooperative companies. ${ }^{104}$ Accordingly, the reference is to high risk of human rights abuse rather than to high risk of conflict. ${ }^{105}$ The last two provisions of the commentary, instead, 'refer to gross abuses with no coupling to high probability of business involvement in such abuses. So even in this case the call towards home states is not dependent on conflict, merely on the grossness of the abuse'. ${ }^{106}$ Gross abuses, therefore, not only occur in situations of armed conflict but, as evidenced in sections II and III of this article, also in various other high-risk contexts, ${ }^{107}$ including when PMSCs are involved in deportation and removals, immigration detention, securing EU 'hotspots' and other processing centres, and providing essential services to refugees and asylum seekers (e.g., access to health care, housing and food). ${ }^{108}$

In these high-risk contexts, the provisions in UNGP 7 are forceful, as they require home states to '[deny] access to public support and services for a business enterprise that

99 UNGP note 18, Principle 7 and related commentary.

100 See Business and Human Rights in Conflict-Affected Regions: Challenges and Options for State Responses, UN Doc. A/HRC/17/32, 27 May 2011.

101 Ibid, para 10.

102 Radu Mares, 'Corporate and State Responsibilities in Conflict-Affected Areas' (2014) 83 Nordic Journal of International Law 293, 311.

103 See, e.g., UNGP 14, 16, 17, 21.

104 Mares (2014), note 102.

105 Ibid.

106 Ibid.

107 See also Special Representative of the Secretary-General, 'Recommendations and Follow-Up to the Mandate', 11 February 2011, https://www.business-humanrights.org/sites/default/files/media/documents/ruggie/ruggie-specialmandate-follow-up-11-feb-2011.pdf, where reference is made to 'armed conflict and other situations of heightened risk' (emphasis added).

108 See, e.g., EASO contracts (2017), note 6, and Lethbridge (2017), also note 6. 
is involved with gross human rights abuses and refuses to cooperate in addressing the situation'. UNGP 7(d) also requires home states to 'ensur[e] that their current policies, legislation, regulations and enforcement measures are effective in addressing the risk of business involvement in gross human rights abuses' ${ }^{109}$ As further emphasized in the addendum report on conflict-affected areas, home states:

should ensure that their regulatory frameworks are adequate, the applicability to business entities is clarified and, for the most extreme situations, make sure that the relevant agencies are properly resourced to address the problem of business involvement in international or transnational crimes, such as corruption, war crimes or crimes against humanity. ${ }^{110}$

Thus, in contrast to objections regarding the existence of an obligation to regulate vested upon the home state, ${ }^{111}$ the nature of high risk of gross abuses, is such that UNGP 7 demands the exceptional engagement of home states, something that in the context of the European Agenda on Migration might be particularly challenging to achieve in practice. Most of the PMSCs involved in implementing EU migration policies, unsurprisingly, are based in EU member states, and represent a sector of major financial significance to the EU, as discussed in section II in relation to their influence and lobbying clout. It is therefore useful to consider, albeit briefly, that there are also additional public procurement obligations vested upon member states purchasing security and other services for the purposes of migration control. ${ }^{112}$ As recognized by the UNGPs, and even more so in these high-risk situations, the state should also be seen as a commercial actor: ${ }^{113}$ purchasing activities by the state thus engage clear international legal obligations and an expectation that the state will be proactive in using public procurement to leverage protection against human rights abuses. ${ }^{114}$

\section{B. An Increased Responsibility to Respect Human Rights for PMSCs}

The UNGPs provide that, in order to fulfil their responsibility to respect human rights, companies should avoid infringing on the rights of others and address negative impacts that they have caused or contributed to. This is to be achieved specifically through

\footnotetext{
109 This is also confirmed by the Commentary to UNGP 7 (note 18), which suggests that states should, inter alia, 'consider multilateral approaches to prevent and address such acts, as well as support effective collective initiatives'.

110 Conflict-Affected Regions Report (2011), note 100, para 13 (emphasis added).

111 As indicated in section I in relation to jurisdiction (note 8), various scholars argue that home states indeed have an obligation to regulate companies domiciled in their territory and/or under their jurisdiction. The Commentary to UNGP 2 , however, took a conservative stance in relation to this debate and stated that '[a]t present States are not generally required under international human rights law to regulate the extraterritorial activities of businesses domiciled in their territory and/or jurisdiction. Nor are they generally prohibited from doing so, provided there is a recognized jurisdictional basis'. The debate is far from settled in international law, as indicated by the vast amount of literature that the topic continues to engender.

112 See further Robert Stumberg et al, 'Turning a Blind Eye? Respecting Human Rights in Government Purchasing' (International Corporate Accountability Roundtable 2014). In the specific context of migration control, EU member states also often procure development aid. For the obligations relevant in development aid procurement, see Annamaria La Chimia, 'Development Aid Procurement and the UNGP: Challenges and Opportunities to Move Forward'; 'The New Frontier of Buying Justice' in Geo Quinot and Sope Williams (eds), Public Procurement Regulations for $21^{\text {st }}$ Century Africa (Cape Town: Juta 2018).

113 This is clearly set out in principles 4-7.

114 See, e.g., Claire M O’Brien et al, ‘National Action Plans on Business and Human Rights: Current Status and Future Prospects for a New Business and Human Rights Governance Tool' (2015) 1 Business and Human Rights Journal 117. See also relevant EU Directives, note 63.
} 
human rights due diligence, ${ }^{115}$ which is substantially aimed at ensuring that a company assesses its actual and potential 'adverse' impacts (in other words, human rights abuses); takes action when such adverse impacts are identified; tracks and communicates to relevant stakeholders the ways in which it addresses such impacts; and contributes to remediating them. In high-risk contexts, such as the ones analysed in this article, PMSCs have a heightened responsibility, including vis-à-vis the type of human rights due diligence that they carry out and the remediation mechanisms that they provide. They should have a clearer understanding of the severity of the abuses that they become involved in and/or contribute to, in terms of scale and scope of the abuses but also in terms of trauma and irremediable nature of the harm. ${ }^{116}$ The focus of the human rights due diligence process, therefore, is not on the risk to the company, but on the higher risk to which refugees and migrants are exposed when PMSCs implement migration control operations. PMSCs should consider both the likelihood and severity of the risk, and that this risk increases proportionally with the negative impact on the people subject to the migration control operations they are contracted to carry out or to otherwise enable.

In the specific securitized and militarized contexts analysed here, direct consultations with affected stakeholders would not be feasible (or highly unlikely) and this is why the UNGPs recommend the use of expert resources to ascertain the human rights concerns related to the activities in which they will be involved. Due to the high risk of gross abuses, UNGP 23(c) is of particular significance to this analysis as it provides that 'businesses enterprises should treat the risk of causing or contributing to gross human rights abuses as a legal compliance issue wherever they operate'. ${ }^{117}$ As already discussed in section III, the need to consider the risk of being involved in gross human rights abuses as a compliance issue is clearly specified in the commentary to UNGP 23(c). The latter, John Sherman posits:

recognizes that regardless of the uncertainty of the law in particular jurisdictions, a company's involvement in gross human rights abuses would be such an egregious calamity for the company and society that its lawyers should proactively monitor the company's efforts to prevent its involvement in such abuse, as they would do to prevent its involvement in any serious corporate crime. ${ }^{118}$

UNGP 23 should be read in conjunction with UNGP 24, as the latter indicates the need to prioritize actions aimed at preventing and addressing adverse impacts. PMSCs involved in high-risk operations, therefore, should not only ascertain the likelihood of their contribution to gross abuses, but should also prioritize action to address the most severe impacts. ${ }^{119}$

In light of the above, it appears that the involvement of PMSCs in the implementation of the European Agenda on Migration might not sit comfortably with the provisions in

\footnotetext{
115 See UNGPs 17-21 and related commentary, note 16.

116 See, e.g., UNGP 24 and related commentary, note 18.

117 UNGP 23(c), note 18, emphasis added. See also Davies, note 96, 967-77.

118 John F Sherman, 'The UN Guiding Principles: Practical Implications for Business Lawyers' (2013) In-House Defense Quarterly at 55, http://shiftproject.org/sites/default/files/Practical\%20Implications\%20for\%20Business\% 20Lawyers.pdf, as referenced in ibid (emphasis added).

119 See Davis (2012), note 96, 977. UNGP 24, note 18, reads: 'Where it is necessary to prioritize actions to address actual and potential adverse human rights impacts, business enterprises should first seek to prevent and mitigate those that are most severe or where delayed response would make them irremediable'.
} 
UNGPs 23 and 24. In particular, by framing refugees and migrants as a 'security threat', influencing EU policy-making to prioritize militarized responses to migration, and then providing the security services ideally placed to address such a prioritized threat, PMSCs might have done the opposite of what is recommended in the UNGPs. Rather than acting to prevent their involvement in gross abuses and treating such risk as a legal compliance issue, they may have actively engaged in increasing the risk of their occurrence, making it more likely in the fragile and complex context of EU migration control.

This article, however, has not been conceived as an indictment against PMSCs and home states, but as a call to further examine both the actions and omission by homes states and companies involved in the implementation of the European Agenda, so that much-needed corrective actions can be taken, not least towards adopting a radically different approach to the European refugee 'crisis', in full compliance with international legal obligations.

\section{Conclusion}

In this article I closely examined the role of PMSCs in implementing EU migration control policies enshrined in the European Agenda on Migration. Three main arguments have been advanced in this contribution to the business and human rights debate: first, I have argued that PMSCs do not merely provide border security and migration control services. They frame, shape and entrench militarized responses within the European Agenda. They contribute to the framing of irregular migration as a security threat which can only be addressed through emergency-driven military responses - and, conveniently, the same services that they provide. Thus, they irreversibly shape European migration policies and accelerate the securitization of the EU border.

I have then argued, in section III, that the context of the activities carried out by PMSCs involved in implementing the European Agenda on Migration meets the conditions of 'high-risk' operations for the purposes of the application of the UNGPs. The presence of a high risk of occurrence of gross human rights abuses, as further discussed in section IV, triggers the applicability of the UNGPs to such contexts, irrespective of the presence of an armed conflict. This point is crucial because it enables the applicability of relevant UNGP standards also in times of peace, whenever there is a risk of involvement in gross abuses.

In the final section of the article, I discussed the heightened obligations of home states and the specific enhanced responsibilities of PMSCs that such a re-conceptualization entails. More specifically, I highlighted the need to acknowledge that home states and PMSCs are falling short of what is expected of them under the UNGPs. This has profound implications, which should be examined by further research on the topic, for issues of jurisdiction, complicity, joint responsibility, and the responsibility of the EU as an international organization. The application of the UNGPs (principles 7 and 23(c) in particular), might contribute to a shift towards the prevention of human rights violations in high-risk situations. Until EU migration policies are driven by the self-perpetuating convergence of interests between the EU and major PMSCs, however, there is little hope that a more human rights-centred approach to the European refugee 'crisis', in full compliance with international law and in line with the UNGPs, will be envisioned. 